\title{
Correction to: From nest site lottery to host lottery: continuous model of growth suppression driven by the availability of nest sites for newborns or hosts for parasites and its impact on the selection of life history strategies
}

\author{
Krzysztof Argasinski $^{1}$ (D) $\cdot$ Ryszard Rudnicki $^{2}$
}

Published online: 10 February 2020

(c) Springer-Verlag GmbH Germany, part of Springer Nature 2020

\section{Correction to: Theory in Biosciences \\ https://doi.org/10.1007/s12064-019-00307-0}

The original version of this article unfortunately contained a mistake. Part of the article title was included as subtitle. The corrected version of title is updated here.

The original article has been corrected.

Publisher's Note Springer Nature remains neutral with regard to jurisdictional claims in published maps and institutional affiliations.

The original article can be found online at https://doi.org/10.1007/ s12064-019-00307-0.

Krzysztof Argasinski

argas1@wp.pl

Ryszard Rudnicki

rudnicki@us.edu.pl

1 Institute of Mathematics, Polish Academy of Sciences, Śniadeckich 8, 00-656 Warsaw, Poland

2 Institute of Mathematics, Polish Academy of Sciences, Bankowa 14, 40-007 Katowice, Poland 